\title{
浅析现代建筑工程项目建设中的绿色节能设计
}

\author{
梁慧丽 \\ 浙江恒欣建筑设计股份有限公司 \\ DOI:10.32629/btr.v3i8.3335
}

\begin{abstract}
[摘 要] 现代建筑工程项目建设要从建筑物所在地的地理, 气候, 日照等条件出发, 使建筑获得更多的可 再生能源。因此为了保障现代建筑工程项目建设的有效性, 本文阐述了现代建筑工程项目建设中的主要 特征及其绿色节能设计原则与要求,对现代建筑工程项目建设中的绿色节能设计要点进行了探讨分析。 [关键词] 建筑项目工程; 规划设计; 特征; 绿色节能设计; 原则; 要求; 要点
\end{abstract}

中图分类号：TU201.5 文献标识码：A

\section{1 建筑节能的定义}

建筑工程项目的内容中, 规划、设 计、新建、改建和使用都有国家发布的 法律法规为依据, 在施工过程中, 必须按 照这些规定来进行设计建造, 达到国家 所规定的节能标准。比如当前的一些建 筑设计中, 我们会采用一些新型的建筑 工艺和技术, 应用一些新型的建筑材料, 滨江这三者有效的结合在一起, 达到我 们预期的保温隔热效果, 这样我们就可 以用更少的能量去为室内供热, 同样可 以达到预期的室内温度, 这样就在很大 程度上减少了能量的消耗, 再有为建筑 供热的能源, 要尽可能的采用可再生能 源, 尽最大的可能去保护好当地的生态 环境, 应用最少的资源去创造一个好的 生存环境。

\section{2 现代建筑工程项目建设的主} 要特征

2.1复杂性

建筑工程建设工作涉及多组织、多 学科等, 并且建筑工程建设的不确定因 素诸多, 使得建筑工程规划设计具有复 杂性的特征。

\section{2 阶段性}

建筑工程建设具有明确的阶段性, 不同阶段一般是通过其任务不同进行划 分。建筑工程的规划设计需要结合不同 阶段的项目内容进行相关工作。

2. 3 具有寿命周期性

建筑工程规划设计是对一次性房地
产工作进行的规划设计, 并且保证建筑 工程的预定目标在规定期限内完成。当 建筑工程目标得到实现, 该项目将最终 解体, 所以说建筑工程的规划设计具有 可以预知的寿命周期。

\section{3 现代建筑工程项目建设中的} 绿色节能设计原则分析

3.1以人为本的原则

现代建筑是为了居住者的需求, 而 绿色节能设计是在减少能源消耗的基础 上, 保障居住者的健康使用, 主要表现 为: 绿色节能设计必须保证室内空气质 量、噪音晃电磁场辐射等符合相关环境 要求。选择材料时应选用低毒或无毒材 料, 减少涂料、木制品、地䎦等对人类健 康有害的材料。绿色节能设计需要自然 采光, 满足居住者的视觉需要, 同时达到 节能效果。

\section{2 和谐原则}

建筑是人们主要居住的场所, 所以 建筑生命周期的每一个环节都有能源的 消耗, 能源的消耗在满足人们日常生活 的前提下, 还需要和社会以及周围的自 然环境进行协调发展。绿色建筑的设计 理念就是低能耗、低污染, 所以绿色建筑 生态节能设计的原则也必须使社会、人 类和自然三者可以和谐共同发展, 只有 严格遵守这一和谐原则, 才能达到绿色 建筑的真正目的。

\section{3环境保护原则}

保护环境是建筑绿色节能设计的主
要原则, 对建筑业发展具有重要影响。在 建筑施工以前, 设计师必须对施工场地 进行大规模数据勘查, 然后整理出详尽 的信息, 再制定环保方案。

4 现代建筑工程项目建设中的 绿色节能设计要求分析

4. 1 降低不必要的能源耗损

建筑工程的科学规划可以达到最小 资源消耗, 同时保障建筑内的冬暖夏凉。 但是现在大多居民楼特征是冬冷夏热, 造成这种情况的原因就是因为其建筑的 围护结构隔热性能不佳。由于其隔热层 的不足, 当处于冬天时, 室内的热量容易 挥发并消失。而在夏天时, 室外的高温又 可以迅速传入室内。所以要想达到绿色 节能提高建筑的宜居性, 做好建筑的围 护结构隔热设计就相当重要。

\section{2 提升建筑节能效率}

(1) 提高自然光线采光利用率。自然 光线是对眼睛与皮肤伤害最小的光线, 天然的节能效果是完全满足现代建筑工 程项目建设中对于绿色节能的要求的。 所以在进行设计时, 应利用尽可能的一 切施工工艺与手段, 把自然光多引入建 筑物内。

(2) 提高对于太阳能的利用率。太阳 能作为最广泛最持续的热源供给, 应用 对于建筑绿色节能来说有着非常重要的 意义。随着科技的发展, 越来越多的太阳 能应用将遍及建筑的供电与供暖方面。

(3) 扩大风能的利用。风能可以转化 
为电能与热能, 应用时多以提高建筑的 通风透气性为主。通过合理布局与设计, 以提高建筑的自然通风度, 达到宜居度 的提升与建筑能耗的降低。

\section{5 现代建筑工程项目建设中的} 绿色节能设计要点分析

5. 1 科学选择建筑项目的地址

现代建筑工程项目建设中的建筑选 址要紧密联系建筑物实际功能, 能否做 到科学、合理地选址, 会直接影响到建筑 物空间的日后使用情况, 且与周围环境 有着重要关联。此外辐射干扰也会给建 筑环境带来较大的消极影响。地块周边 若有较大面积的高层建筑或玻璃幕墙, 均会以反射形式促进地块局部气温的升 高, 进而导致小片区域的温室效应。城市 中的光源, 如果使用过量, 就会形成光污 染, 这也会对人类的正常活动造成较大 的影响, 且严重影响到了人体的身心健 康。因此建筑选址应尽量避开以上区域, 也可以采取有效的绿化手段消减这些因 素带来的环境污染问题。

\section{2 门窗绿色节能设计}

门窗结构的位置是处于建筑物的最 外层, 是与空气直接接触的, 是保证空气 可以从门窗的缝隙中渗透到室内, 对室 内的温度会有一定的影响, 但是它对隔 热保温的作用并不大, 因此在建筑设计 过程中做到优化门窗是节能环保的重要 设计项目。这需要保证窗户占墙面的比
例适中, 以便于控制热能消耗量; 门窗 开关类型要合理, 避免室内空气对流; 门窗适当加入遮阳帽, 便于控制室内阳 光摄入量, 平衡室内温度, 保证室内最 佳状态。

\section{3 规范建筑间距}

绿色节能设计中的建筑物间距要结 合当地的日照情况, 日照标准, 绿色节能 设计原则及防火规范等因素综合考虑, 建筑的间距要根据当地在冬至日的太阳 高度角进行合理的计算, 计算出的间距 要保证住宅室内有一定量的日照, 还需 要有一定的日照时间来提高室内的温度, 减少空调的能耗, 从而达到节能的目的。 在规划中还可以适当加大部分建筑物间 的间距, 对改善建筑物之间的通风有良 好效果。

5.4 结合实际选择建筑朝向

建筑朝向是指建筑物正南立面的法 线与正南方向的夹角, 朝向的选择涉及 到建筑物的地理特点, 气候环境, 建筑用 地等等情况。在寒冷季节获得更多的日 照, 房间内避免寒风侵袭; 酷热季节减少 太阳辐射, 并有良好通风, 同时也要照顾 到其他建筑物的需要。

5. 5 加强对新型能源的使用

近些年来, 随着我国煤炭、石油及天 然气等能源的大量使用, 能源贵乏已经 成为了当前的重点问题, 基于此, 加强对 新能源的使用是现阶段建筑行业发展的
重要趋势, 因此, 在建筑节能设计的过程 中, 加入对太阳能的使用可以在很大程 度上提高节能效果。主要内容可以归纳 为以下几个方面: 首先是太阳能热水器, 该项技术已经逐渐成熟, 且受到了广泛 的应用, 太阳能热水器在使用过程基本 不会涉及到运行费用, 且太阳能热水器 的使用年限也能达到十年至二十年之间, 在节约能源的基础上也能实现成本的节 约; 其次是太阳能发电, 太阳能发电系统 是通过对太阳光原理的利用, 而制成的 一种发电系统, 该发电系统可以将太阳 辐射直接转化为电能。

\section{6 结束语}

综上所述, 现代建筑工程项目建设 中的绿色节能设计不仅可以提高能源利 用率, 促进建筑业的健康发展, 还能保护 生态环境, 使得建筑绿色节能设计工作 日显重要。因此对现代建筑工程项目建 设中的绿色节能设计进行分析具有重要 意义。

\section{[参考文献]}

[1]吴文文.浅析建筑规划设计中 的建筑节能设计 [J].建筑工程技术与设 计,2017,(023):5009.

[2]黄澄.建筑规划设计中节能建筑的 设计探讨[J].城市住宅,2020,27(1):218-219.

[3] 谢丽娟.浅谈建筑设计中节能建 筑设计[J].砖瓦,2020,(08):69-70. 